\section{UCT1072s, New Antitumor Antibiotics with Topoisomerase II Mediated DNA Cleavage Activity, from Aspergillus sp.}

\author{
Akira ASai*, Yoshinori Yamashita, Katsuhiko Ando, \\ SHINGO KaKITA, KatSUNORI KITA ${ }^{\dagger}$, YASUHIRO SUZUKI ${ }^{\dagger}$, \\ Akira MiHara ${ }^{\dagger}$, Tadashi AshizaWa ${ }^{\dagger}$, Tamio MizuKami ${ }^{\dagger \dagger}$ \\ and HIROFUMI NAKANO \\ Tokyo Research Laboratories, Kyowa Hakko Kogyo Co., Ltd., \\ 3-6-6 Asahi-machi, Machida-shi, Tokyo 194-8533, Japan \\ † Pharmaceutical Research Laboratories, \\ Kyowa Hakko Kogyo Co., Ltd., \\ 1188 Shimotogari, Nagaizumi-cho, Sunto-gun, \\ Shizuoka 411-8731, Japan \\ (Received for publication July 13, 1999)
}

DNA topoisomerase II is a nuclear enzyme that alters DNA conformation through a concerted breakage and rejoining of DNA strands, thereby controlling the topological state of DNA. Topoisomerase II has been shown to be the primary cellular target for a number of clinically important antitumor agents with diverse and unrelated chemical structure ${ }^{1)}$. These antitumor drugs, referred to as "topoisomerase II poisons", trap the enzyme in an intermediate complex with DNA which prevents the final rejoining step of the reaction and results in increased DNA strand breaks ${ }^{2)}$. Now it is generally accepted that the ability to form a cleavable complex with topoisomerase II is responsible for the antitumor activity of these drugs ${ }^{3}$.

In order to identify a specific new topoisomerase II poison, we have screened microbial metabolites and plant extracts for their ability to induce topoisomerase II mediated DNA cleavage in vitro ${ }^{4-6)}$. We describe here isolation and antitumor activity of novel anthraquinonederivatives including UCT1072M1, M2 and M3, potent inducers of topoisomerase II mediated DNA cleavage from the culture broth of Aspergillus sp.

The producing organism KY4915 was isolated from a soil and assigned to the genus Aspergillus. Fermentations were carried out at $30^{\circ} \mathrm{C}$ for 91 hours with appropriate aeration and agitation in $2 \mathrm{k}$-liter tank fermenter containing the $1 \mathrm{k}$ liter of culture medium consisting of soluble starch $5 \%$, corn steep liquor $2 \%, \mathrm{KH}_{2} \mathrm{PO}_{4} 0.05 \%, \mathrm{MgSO}_{4} \cdot 7 \mathrm{H}_{2} \mathrm{O}$ $0.05 \%, \mathrm{Mg}_{3}\left(\mathrm{PO}_{4}\right)_{2} \cdot 8 \mathrm{H}_{2} \mathrm{O} 0.05 \%, \mathrm{pH} 7.0$. UCT $1072 \mathrm{M} 1$ was accumulated in the culture medium. The culture filtrate was applied to a column of Diaion HP-20 (Mitsubishi Chemical Industries Limited). The column was washed with deionized water-MeOH $(1: 1)$ and eluted with $\mathrm{MeOH}$. The active eluate was concentrated and applied to a column of ODS-AQ-50 (YMC). The column was washed with $\mathrm{CH}_{3} \mathrm{CN}$ $10 \mathrm{mM}$ phosphate buffer (pH 5.5) (3:7) and eluted with $\mathrm{CH}_{3} \mathrm{CN}-10 \mathrm{~mm}$ phosphate buffer (pH 5.5) (4:6). The eluate was concentrated and extracted with EtOAc. The extract was concentrated and further purified by a silica gel column chromatography (Licroprep Si60) using n-hexane acetone-acetic acid $(100: 30: 1)$ as an eluent. The active fractions were combined and concentrated to yield $282 \mathrm{mg}$ of UCT1072M1 as a yellow powder. Minor products UCT1072M2 (2 mg) and M3 (2 mg) were also obtained from the culture broth of KY4915. The physico-chemical properties are summarized in Table 1. All of the UCT1072s were readily soluble in DMSO, $\mathrm{MeOH}$ but insoluble in $\mathrm{H}_{2} \mathrm{O}, \mathrm{CHCl}_{3}$ and $n$-hexane. ${ }^{1} \mathrm{H}$ and ${ }^{13} \mathrm{C}$ NMR spectroscopic studies elucidated that all of them were new anthraquinone analogs. Structures of the UCT1072s are shown in Figure 1. UCT1072M1 was a hydroxyl derivative of versicolorin B that is known as an one of intermediates in aflatoxin biosynthesis pathway ${ }^{7}$. UCT1072M3 was a diastereomer of UCT1072M2. The stereochemistry of UCT1072M3 has not yet determined, but NOE experiments indicated the putative structure shown in Figure 1. The details of structure determination and chemical properties of the UCT1072s will be reported elsewhere.

The effect of the UCT1072s on mammalian topoisomerase II was tested using the biochemical assay ${ }^{4)}$ and the cellular assay system ${ }^{8)}$. The topoisomerase II mediated DNA cleavage activity of the UCT1072s was examined in vitro using purified calf thymus topoisomerase II and plasmid pBR322 DNA. Fig. 2A shows a photograph of agarose gel electrophoresis comparing the topoisomerase II mediated DNA cleavage activity of the UCT1072s. In the presence of topoisomerase II, all of the UCT1072s gave the linear full length DNA as a result of DNA double strand cleavage. In the absence of topoisomerase II, the UCT1072s did not induce any change on the supercoiled structure of pBR322 DNA. Since topoisomerase I mediated DNA cleavage activity by the UCT1072s was not observed, these antibiotics are selective topoisomerase II poisons (data not shown). The potency of the DNA cleavage activity quantified by the amount of linear DNA is UCT1072M1 $\geq$

\footnotetext{
${ }_{\dagger}$ Present address: Pharmaceutical Research \& Development Center, Kyowa Hakko Kogyo Co., Ltd., 1-6-1 Ohte-machi, Chiyoda-ku, Tokyo 100-8158, Japan.
} 
Table 1. Physico-chemical properties of UCT1072s.

\begin{tabular}{|c|c|c|c|}
\hline & UCT1072M1 & UCT1072M2 & UCT 1072M3 \\
\hline Appearance & Yellow powder & Yellow powder & Yellow powder \\
\hline $\mathrm{MP}\left({ }^{\circ} \mathrm{C}\right)$ & $>300$ & $241-242$ & $160-163$ \\
\hline$[\alpha]_{D}^{26}$ & $-356^{\circ}$ [c 0.274, DMSO $]$ & $-720^{\circ}[\mathrm{c} 0.174, \mathrm{DMSO}]$ & $+64.8^{\circ}[\mathrm{c} 0.174, \mathrm{DMSO}]$ \\
\hline Molecular weight & 356 & 368 & 368 \\
\hline Molecular formula & $\mathrm{C}_{18} \mathrm{H}_{12} \mathrm{O}_{8}$ & $\mathrm{C}_{20} \mathrm{H}_{16} \mathrm{O}_{7}$ & $\mathrm{C}_{20} \mathrm{H}_{16} \mathrm{O}_{7}$ \\
\hline FAB-MS (m/z) & $357(\mathrm{M}+\mathrm{H})^{+}$ & $369(\mathrm{M}+\mathrm{H})^{+}$ & $369(\mathrm{M}+\mathrm{H})^{+}$ \\
\hline \multirow[t]{2}{*}{ HRFAB-MS (m/z) } & Found $357.0601(\mathrm{M}+\mathrm{H})^{+}$ & Found $369.0993(\mathrm{M}+\mathrm{H})^{+}$ & Found $369.0987(\mathrm{M}+\mathrm{H})^{+}$ \\
\hline & Calcd. 357.0610 & Calcd. 369.0975 & Calcd. 369.0975 \\
\hline \multirow[t]{2}{*}{$\mathrm{UV} \lambda_{\max }{ }^{\mathrm{DMSO}} \mathrm{nm}$} & $292(22000), 330$ (11000), & $294(36000), 333(14000)$, & $293(20000), 332(9300)$ \\
\hline & $456(5600)$ & $459(8400)$ & $459(4700)$ \\
\hline IR $v_{\max }(\mathrm{KBr}) \mathrm{cm}^{-1}$ & $\begin{array}{l}3410,1628,1308,1296 \\
1190,1024\end{array}$ & $\begin{array}{l}3420,1628,1608,1394 \\
1385,1309,1288\end{array}$ & $3344,1624,1311,1294$ \\
\hline
\end{tabular}

Fig. 1. Structures of UCT1072M1, M2 and M3 and versicolorin B.

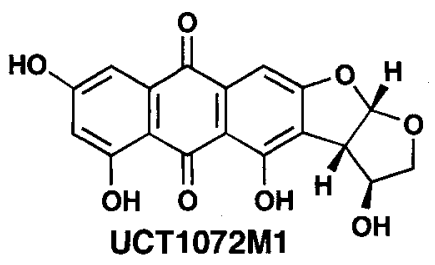<smiles>O=C1c2cc(O)cc(O)c2C(=O)c2c1cc1c(c2O)[C@H]2CCCC[C@H]2O1</smiles>

UCT1072M2

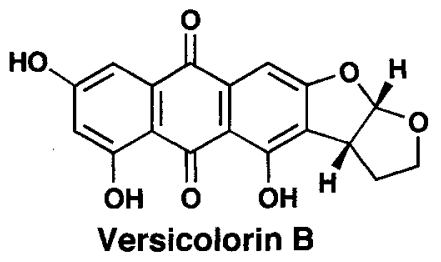

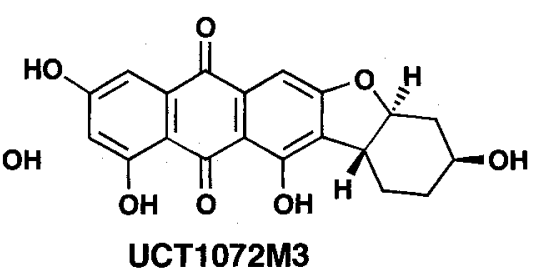

UCT1072M3>UCT1072M2. The activity of UCT1072M3 was significantly different from that of its diastereomer UCT1072M2. This observation showed the importance of stereochemistry on the moiety fused together anthraquinone skeleton. We next examined the induction of covalent protein-DNA complex by these drugs in HeLa S3 cells using $\mathrm{K}^{+} / \mathrm{SDS}$ precipitation assay. All of the tested compounds induced complex formation in dose dependent manner (Fig. 2B). A good correlation between the topoisomerase II mediated DNA cleavage activity in vitro and the activity on the protein-DNA complex formation in cells indicated that the UCT1072s stabilize the topoisomerase II-
DNA cleavable complex in cells. Furthermore, the potency of cytotoxic activity against HeLa S3 or Lu-65 cells shown in Table 2 was consistent with the data obtained by these topoisomerase II-based assay systems. On the basis of these results we suggest that the UCT1072s act as the topoisomerase II poison in cells and this mode of action contribute to the cytotoxic activity of these compounds against tumor cells. In spite of showing more potent activity than a known topoisomerase II poison VP-16 in vitro (Percentage of linear DNA was $35 \%$ at $50 \mu \mathrm{M}$ VP-16 in the same assay described in Fig. 2A.), UCT1072M1 showed weaker cytotoxic activity than VP-16 at 72 hours-exposure 
Fig. 2. UCT1072s induce topoisomerase II mediated DNA cleavage in vitro and protein-DNA complex formation in cells.

A

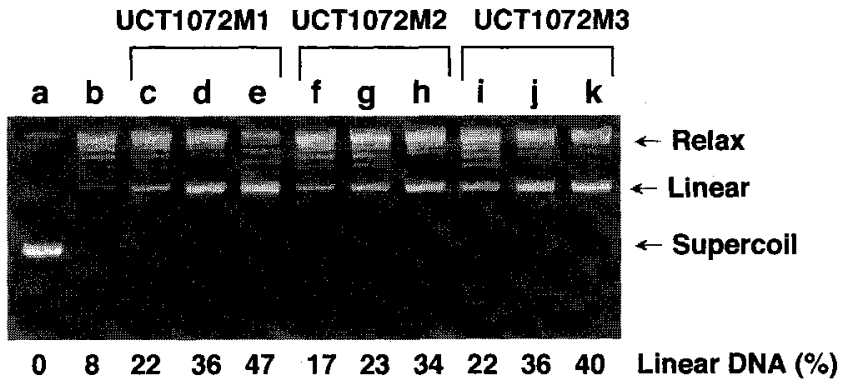

B

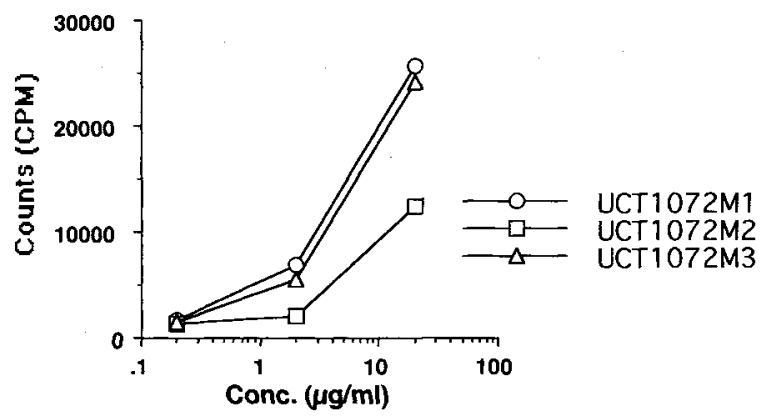

A: Topoisomerase II mediated DNA cleavage activity of UCT1072s was carried out as described previously ${ }^{4)}$ Lane a, covalently closed circular DNA control; lane b, no drug; lane $\mathrm{c} \sim \mathrm{k}$, UCT1072s. Drug concentrations were as followed: Lanes c, f and i, $2 \mu \mathrm{M}$; lanes $\mathrm{d}, \mathrm{g}$ and j, $10 \mu \mathrm{M}$; lanes e, h and $\mathrm{k}, 50 \mu \mathrm{M}$. The percentage of linear DNA quantified by densitometric analysis was represented at the bottom of panel $\mathrm{A}$.

B: Amount of protein-DNA complex in drug-treated HeLa $\$ 3$ cells was measured by K+/SDS precipitation method $^{7)}$

(Table 2). It is presumed that UCT1072M1 might be unstable in cells, because the comparable cytotoxic activity of UCT1072M1 to VP-16 was observed when cells were incubated with these antibiotics for 1 hour (Table 2). UCT1072M1 was explored to examine antitumor activity in vivo. Following daily i.p. treatment $(38 \mathrm{mg} / \mathrm{kg} /$ day, days $1 \sim 5$ ) of UCT1072M1 to mice bearing the murine tumor sarcoma 180 , a moderate decrease $(\mathrm{T} / \mathrm{C}=0.5)$ in tumor volume in vivo was observed. Thus, this class of antibiotic could be a family of naturally occurring new lead compounds for anticancer chemothrapy, which target topoisomerase II in tumor cells.

\section{Acknowledgments}

The authors are grateful to Ms. HiroKo TANABE, Machi KUSUNOKI and Mr. NAOYUKI HIRAOKA for technical assistance.
Table 2. Cytotoxic activity of UCT1072s against human tumor cell lines.

\begin{tabular}{lccccc}
\hline & \multicolumn{3}{c}{$\mathrm{IC}_{50}(\mu \mathrm{M})$} \\
\cline { 2 - 3 } & \multicolumn{3}{c}{ HeLa S3 } & & \multicolumn{2}{c}{ Lu-65 } \\
\cline { 2 - 3 } \cline { 5 - 6 } Compound & $1 \mathrm{hr}$ & $72 \mathrm{hr}$ & & $1 \mathrm{hr}$ & $72 \mathrm{hr}$ \\
\hline UCT1072M1 & 1.9 & 2.1 & & 2.3 & 2.2 \\
UCT1072M2 & 8.5 & 8.9 & & $>10$ & $>10$ \\
UCT1072M3 & 5.4 & 2.7 & & 4.3 & 3.2 \\
VP-16 & 2.4 & 0.11 & & 3.5 & 0.17 \\
\hline
\end{tabular}

( $\mathrm{IC}_{50}$ was calculated with XTT assay)

\section{References}

1) Bodley, A. L. \& L. F. LiU: Topoisomerase as novel target for cancer chemotherapy. Biotechnology 6: 1315 
1357,1988

2) LiU, L. F.: DNA topoisomerase poisons as antitumor drugs. Annu. Rev. Biochem. 58: 351 375, 1989

3) Burdent, D. A. \& N. OsherofF: Mechanism of action of eukaryotic topoisomerase II and drugs targeted to the enzyme. Biochim. Biophys. Acta 1400: 139 154, 1998

4) Yamashita, Y.; S. KaWada, N. Fuji \& H. NAKano: Induction of mammalian DNA topoisomerase I and II mediated DNA cleavage by saintopin, a new antitumor agent from fungus. Biochemistry 30: 5838 5845, 1991

5) KaWAdA, S.; Y. YamashiTa, Y. UOSAKI, K. Gomi, T. IWASAKI, T. TAKIGUCHI \& H. NAKANO: UCT4B, a new antitumor antibiotic with topoisomerase II mediated DNA cleavage activity, from Streptomyces sp. J. Antibiotics 45: 1182 1184, 1992
6) Fuji, N.; Y. Yamashita, Y. Arima, M. Nagashima \& H. NAKANO: Induction of topoisomerase II-mediated DNA cleavage by the plant naphtoquinones plumbagin and shikonin. Antimicrobial Agents and Chemotherapy 36: 2589 2594, 1992

7) Aucamp, P. J. \& C. W. Holzapfel: Polyhydroxyanthraquinones from Aspergillus versicolor, Aspergillus nidulans, and Bipolaris sp. Their significance in relation to biogenetic theories of aflatoxin B1. J. S. Afr. Chem. Inst. 23: 40 56, 1970

8) Fuji, N.; Y. Yamashita, T. Mizukami \& H. Nakano: Correlation between the formation of cleavable complex with topoisomerase I and growth-inhibitory activity for saintopin-type antibiotics. Molecular Pharmacology 51: 269 276, 1997 